\title{
The Relation Between Infrastructure Quality and Government Effectiveness in Egypt.
}

\author{
Mustafa Elnemr \\ Department of Political Sciences and International Relations \\ Institute of Social Sciences \\ İstanbul Aydin Universitesi \\ Email: Mustafa.elnemr@eipss-eg.org \\ Turkey
}

\section{Abstract}

The article examines the relationship between infrastructure quality and government effectiveness in Egypt. The hypothesis is that public private partnership can help Egypt increase its infrastructure efficiency and lower burden in government budget.

The paper conclude that Egypt have a considerable opportunity to finance its infrastructure investment gap through private investment. Public-Private partnership could be adopted as it provides the fastest gains in efficiency.

\section{Keywords: infrastructure, governance, Egypt \\ INTRODUCTION}

Infrastructure includes several sectors. Economic, administrative and social sectors are the main ones. The economic sector includes telecommunications, electricity, railways, airport, seaports, water and sanitation. The social sector involves the education and health sectors. While the administrative sector includes all government apparatus sectors.

Some countries shifted toward private sector through public-private partnership or privatization to fund their projects (حافظ, 2019). However, the public sector has a significant role in funding some of the infrastructure projects due to their importance or sensitivity (الوهاب, 2013)

Egypt depended mainly on the public sector to fund its projects. While this can be positive in terms of economic return to the overall economy, yet the results show an investment gap of over USD 650 billion according to world bank (2018).

This paper will discuss how the low quality of infrastructure affects government effectiveness negatively in Egypt. It will review infrastructure in four sectors; electricity, water, Suez Canal and transportation. In all foursection public investment surpassed private sector enormously. However, the percentage of infrastructure to GDP did not exceed $4 \%$. That affected the quality of infrastructure according to the global competitiveness index where Egypt ranked 100 globally in 2014. In 2017 the government started to apply the public-private partnership approach which resulted in the positive evaluation and made Egypt rank 71 in the latest report.

This paper reviews the four-sections in Egypt and how they affect government effectiveness. The study measures governance quality by analyzing infrastructure quality.

\section{Research Methodology}

Measuring an abstract concept like governance would be very difficult as it reflects many underlying concepts like government effectiveness, regulatory quality, corruption level, political stability, freedom of speech ...etc. Those concepts are too numerous to discuss. To avoid that this paper will only discuss the concept of government effectiveness which can be measured using world governance indicator.

The World Bank developed world governance indicator to compare governance performance between countries. The indicator has six dimensions; voice and accountability, political stability and absence of violence, government effectiveness, regulatory quality, rule of law and control of corruption. 
Government effectiveness indicator (GE) captures the perception of many underlying representative resources. The concept measures over 40 underlying indicators. For example, quality of public administration, institutional effectiveness, excessive bureaucracy, quality of primary education, infrastructure, policy instability, quality of budgetary and financial management ...etc.

In this study, I will focus only on infrastructure quality. There are two reasons for selecting this subconcept. First is that infrastructure resonating with the large number of the underlying concepts that GE measures. For example, satisfaction with the public transportation system, satisfaction with roads and highways, coverage area: drinking water and sanitation, coverage area: electricity grid, coverage area: transport infrastructure, coverage area: maintenance and waste disposal and infrastructure disruption concepts can be analysed under the infrastructure quality.

Second, it would be hard to analyze all the measured concepts separately due to the time limitation and the size of the study which made it essential to select certain areas and analyze them.

The next step would be how to analyze infrastructure quality. I will use the global competitiveness index (GCI). The report views the competitiveness from a productivity point of view as it states "we understand national competitiveness as the set of factors, policies, and institutions that determine the level of productivity of a country. Raising productivity meaning-making better use of available factors and resources is the driving force behind the rates of return on investment which, in turn, determine the aggregate growth rates of an economy. Thus, a more competitive economy will be one which will likely grow faster in a medium to long-term perspective" (AUGUSTO, et al., 2006, p. 3).

The latest reports measure 12 pillars to determine an aggregated global competitiveness index (GCI), institution, Infrastructure, Macroeconomic environment, Health and primary education, Higher education and training, Goods market efficiency, Labor market efficiency, Financial market development, Technological readiness, Business Sophistication, and Innovation.

For this study, I will use only the infrastructure pillar. The second pillar, which is the infrastructure, capture quality of infrastructure in terms of quality of transportation, energy, and telecommunications. In this part, I will analyze models of investment in both countries and how it affects infrastructure quality. The period of the data collected from both WGI indicator and GCI is between 2007-2017 due to data availability. The global competitive report was published public yearly since 2007 while World governance indicator latest update is 2017 .

The study will be composed of the following; first, it will review the literature of governance theories and how to measure governance quality. Then it will analyze the relationship between infrastructure and government effectiveness. Then it will discuss in-depth infrastructure trends in Egypt. Finally, it will provide policy recommendations to improve infrastructure quality.

\section{Governance Theories}

The New Public Management marks the beginning of public sector reform which started in the 1980s. It occurred in two principal waves. The first wave agenda which was introduced by NPM theorists pushed to increase the market role and applying corporate management methods in the public sector at the expense of the state. (Bang, 2003) During the second wave, several networks advocated to revive the role of state again and importance of public sector again where some of them were responsive to the consequences of the first wave (Bevir, 2007).

The NPM which was the first wave was inspired by the neoliberal ideas and public choice. NPM started in the United States before going through Europe and then developing countries. The main principles for NPM are efficiency, effectiveness and user orientation (Katsamunska,2016). The way to implement those principles is by minimalizing the role of the state. The state ensures the delivery of the services to the people but not providing public service and products.

NPM works parallel in two lines to minimize the role of the state: increase market freedom and corporate management (Cheema \& Rondinelli,2007). To increase market freedom, NPM argues that privatization would be the solution. Privatization means private sector obsession of the state ownership of assets. Industries that were privatized 


\section{(C) Center for Promoting Education and Research}

WWW.cpernet.org

included railways, waste-services, electricity, telecommunications, and water. Besides, privatization occurred to smaller size projects like the parking services, conferences centers, hotels. Some of them were sold by the local government while others were sold by the state ( Jäger \& Köhler,2007).

Marketization has other forms like contracting out and consumer choice. Contracting out or outsourcing means the state to contract with private organization and ensure the quality of service provided. The state plays the supervisor role where it does not provide the product but chose the provider in a competitive basis (Kickert, 1997).

Quasi-market emerges as the market is open to competitiveness between different private sectors. That creates multiple choices for the public to select their service provider and compare between them (Johnson, 1997). On the contrary, that will minimize the public right to get subsidized services or free of charge products. If there is no clear distinction between public and private properties that will make public property liable to the vulnerability of privatization.

The second strand is corporate management reform introduced performance incentives. "it means applying to the public-sector ideas and techniques from private-sector management. The main ideas and techniques involved are management by results, performance measures, value for money, and closeness to the customer, all of which are tied to various budgetary reforms." (Bevir,2007, p.369). The premise of managing state as a corporate will affect the budgetary reform to maximize profits and minimize losses.

\section{Networks, Partnerships, and Inclusion}

Public-sector reforms are a continuous process. The second wave of reform was paved away because of managerial reform. This wave focused on institutional capacity and administrative values (الحميلي, 2018). The growing sensitivity to new challenges like terrorism, environmental problems, asylum seekers, digital development and aging populations resulted that people returned to the state seeking for solutions rather than the markets. Bevir discussed the changing content of the public-sector reforms. He said that NPM had led to the fragmentation of the public sector as "public services are delivered by networks composed of several different organizations, there is a new need to coordinate and manage networks" (2007, p. 370). Observers also emphasized the dilemmas of accountability that NPM had raised as it is not always easy to hold accountable for issues like equity even if delivering the service is more efficient (Bevir, 2007).

The main motive for the second wave is to improve the coordination between the agencies. Networks were formed to promote vertical and horizontal coordination between the institutions which provide public service. Joined-up governance generated the idea of collaboration between public and private organizations (Bang,2003).

Public-Private partnership PPP is an example of joined-up governance. It has numerous advantages as it can benefit from the assets of all sectors. For example, "they can ease the burden of capital investment on the public sector while reducing risks of development for the private sector." (Bevir,2007). Partnership and joined-up governance are presented as a way of promoting social inclusion as well as raising the level of efficiency. In the second wave governing is neither the responsibility of state nor the private sector alone. It activated and emphasized the role of collaboration between them (Behn,2001). Civil society role also was activated as a result of that new public-sector reform which introduced the term of good governance.

\section{Good governance}

The United Nation identifies eight major characteristics. It is participatory, consensus-oriented, accountable, transparent, responsive, effective and efficient, equitable and inclusive and follows the rule of law. It aims to minimize corruption, make sure the voices of minorities delivered and implementing interactive role between decision-makers and society. The UN Development Program (UN, 2009) describes the 8 principles as following:

\section{- Participation:}

It means participations action from both genders in direct and indirect methods. Participation should be through representation or an intermediary institution. However, representation does not ensure that all voices 
are heard that why participation should be done in a freedom environment in collaboration with the civil society to reach out every section of the society.

\section{- Rule of law:}

It means that the legal framework is implemented fairly Legal framework should protect human rights especially those of minorities.

\section{- Transparency:}

It means that there is a pattern of regulations for decision making and rule enforcement. Besides, it implies that information is accessible in an easy manner and available free of charge to those who will be affected if those policies were implemented. It also requires that information should be normative and easily comprehensible to those of concern.

\section{- Responsiveness:}

Good governance requires that institutions serve the stakeholders within an adequate timeframe.

\section{- Consensus oriented:}

In any given society there are many actors and interest group. Good governance requires that all those different views to be discussed to reach a mediated consensus between all interest groups. The aim is to reach a wide consensus for what is best to the whole community and how to implement those views. This can only result from an understanding of the historical, cultural and social contexts of a given society or community.

\section{- Equity and inclusiveness:}

This means that all members of society were part of it and not excluded. This requires that all members have equal opportunities to participate and improve their society.

\section{- Effectiveness and efficiency:}

It means that institutions accomplish results that are in benefit of people and meet their requirement while at the same time make the best use of public resources and allocations. It also covers the sustainable natural resources usage as well as protection of the environment.

\section{- Accountability:}

It means that all actors are held into account which means not only governmental performance but also private actors and civil society. However, who would be held accountable and in front of whom depend on the type of actions whether they are internal or external. Each actor should be held accountable in front of their stakeholders who would be affected by decision making. It is important also to emphasize that accountability cannot work without transparency or enforcement of the law.

Those principles make good governance an ideal concept which is difficult to achieve in totality. However, to ensure sustainability in human development, those principles must be taken into consideration.

The Canadian international development agency CIDA defines good governance as the ability to manage social and economic resources of the country. The agency refers to word good as multiple levels of the government exercise their role in an accountable, transparent, honest, effective and equitable manner (Johnson,1997). The definition as it appears is restrictive. It minimized the role of governing to the government alone. It does not consider civil society, private actors and different stakeholders.

To sum up, Governance has a wide spectrum of definitions and it could be used to fulfil different perspectives. The definitions discuss the normative assumptions about how decision making should be made within organizations. Some scholars use the term governance to describe different types of the regime even older than the public sector reform in the 1980s whether democratic, authoritarian, tyranny, royal ruling ... etc.

The NPM was the first wave of public-sector reform to the Weberian state (Lahcen \& Rafik,2016 ). NPM introduced the idea that different actors are essential in the decision-making process. It tried to minimize the role of the state in favor of the private sector. The NPM has its origins in public-choice theory and managerialism which 


\section{(c) Center for Promoting Education and Research}

WWW.cpernet.org

emphasized the role of individualistic choice and get its reflection on the economic situation (Mitchell, 2007). It gave the priority to the market and minimized the role of the state to supervise rather than provide the services.

But with new challenges like terrorism, environmental problems and an ageing population that required intervention from the state as people ran to it seeking solutions. The role of the state becomes more important than just supervising like in NPM and should be less controlling like in Weberian state. The new model of mixed governance resulted in many types of governance "joined-up governance," "one-stop government," "service integration," "whole of government," or "Aktivierender Staat" (activating state) (Bevir,2007) where the state "steer" more than "rule". In short good governance now can be understood as a mix between three elements, the state, the private sector, and civil society.

\section{How to Measure Governance?}

To measure governance, I will use the world governance indicator WGI. The indicator was developed by two researcher Daniel Kaufmann and Aart Kraay as a part of the world bank project to measure governance. since 1997 they used WGI to compare governance quality between 200 countries. WGI is composed of six indicators to measure governance which are; Voice and Accountability, Political Stability and Absence of Violence, Government Effectiveness, Regulatory Quality, Rule of Law and Control of Corruption. They based the indicators on several hundreds of variables collected from 31 different data source (Kaufmann, et al., 2010).

World Bank has introduced several definitions to governance. in 2002, the world Development Report defined governance as "rules, enforcement mechanisms and organizations" (World Bank,2002). This definition is very wide that it covers almost everything. Other definitions focus on the managerial issues of public-sector like proposed in 1992 as the way power is used to manage socioeconomic resources of the country.

According to the WGI project, governance would mean the institutions and traditions that are used to defined governance as the traditions and institutions that are used to exercise power in the state (Adcock \& Collier, 2001). The project aggregated that definition from several notions of governance. according to the project definition, governance would include the selection process of the government as well as monitoring and replacing it. It also includes government capabilities to design and implement proper policies and finally respect citizen's freedom and independence of the institutions that manage socioeconomic challenges (Kaufmann, et al., 2010). The definition covers three broad aspects, first is the democratic process in the country where the ability to select and remove the regime is available. Second government quality in terms of designing and applying policies. Finally, it assumes that there are existing institutions and it tries to measure its performance.

They formed two measures of governance for each of the three areas of the definition. That means that the WGI has six dimensions to measure the governance in a specific country (Kaufmann, et al., 2019):

- The process by which governments are selected, monitored and replaced:

- Voice and Accountability (VA) capturing perceptions of the extent to which a country's citizens can participate in selecting their government, as well as freedom of expression, freedom of association, and a free media.

- Political Stability and Absence of Violence/Terrorism (PV) capturing perceptions of the likelihood that the government will be destabilized or overthrown by unconstitutional or violent means, including politically-motivated violence and terrorism.

- The capacity of the government to effectively formulate and implement sound policies:

- Government Effectiveness (GE)capturing perceptions of the quality of public services, the quality of the civil service and the degree of its independence from political pressures, the quality of policy formulation and implementation, and the credibility of the government's commitment to such policies.

- Regulatory Quality (RQ)capturing perceptions of the ability of the government to formulate and implement sound policies and regulations that permit and promote private sector development.

- The respect of citizens and the state for the institutions that govern economic and social interactions among them: 
- Rule of Law (RL) capturing perceptions of the extent to which agents have confidence in and abide by the rules of society, and in particular the quality of contract enforcement, property rights, the police, and the courts, as well as the likelihood of crime and violence.

- Control of Corruption (CC)capturing perceptions of the extent to which public power is exercised for private gain, including both petty and grand forms of corruption, as well as "capture" of the state by elites and private interests.

The WGI sources for governance data are perceptions-based. That includes the date from companies and households' surveys, assessment of business information providers, non-governmental organizations, public sector, and multilateral organizations. They collect the data from different sources for each indicator and then combine them into a composite indicator that summarizes their common component (Kaufmann, et al., 2010)

Every individual variable had been rescaled from zero to one, with higher values means better results. WGI measures have two ways to describe: from 2.5 to 2.5 which is called the standard normal units or with percentile ranking from 0 which marks the lowest rank to 100 which means the best governance (Kaufmann, et al., 2007). The measurement can be used to compare scores between countries through each indicator, however, those comparisons are subjected to the margin of errors. Each indicator measures several concepts under them. To aggregate, those data into one resulted they used unobserved component model (UCM). This model is a statistical tool that is used to aggregate Large- $\mathrm{N}$ data.

\section{Egypt: infrastructure effect on government effectiveness}

Over the last decade, there has been a decline in some area of infrastructure, particularly transportation and water. Associated with this decline, capital expenditure in Egypt has been reduced which raise the concern that the country could go through an unsustainably low level of infrastructure investment.

This part will examine the relationship between the infrastructure pillar using the Global Competitiveness Index and Government effectiveness using World Governance Index. Then I will discuss the expenditure trends in four infrastructure sectors; transportation, water, electricity and Suez Canal. And finally, I will evaluate how expenditure on infrastructure will improve the quality of government.

\section{Infrastructure and GE relation}

Figure 1 shows the correlation between the infrastructure pillar from the Global Competitiveness Index and Government Effectiveness from World Governance Indicator. The infrastructure line is scaled from 1-7 with 1 means lowest performance and 7 means the best performance. Government effectiveness is a measure between 1100 with 1 means the lowest percentage and 100 means the best performance.

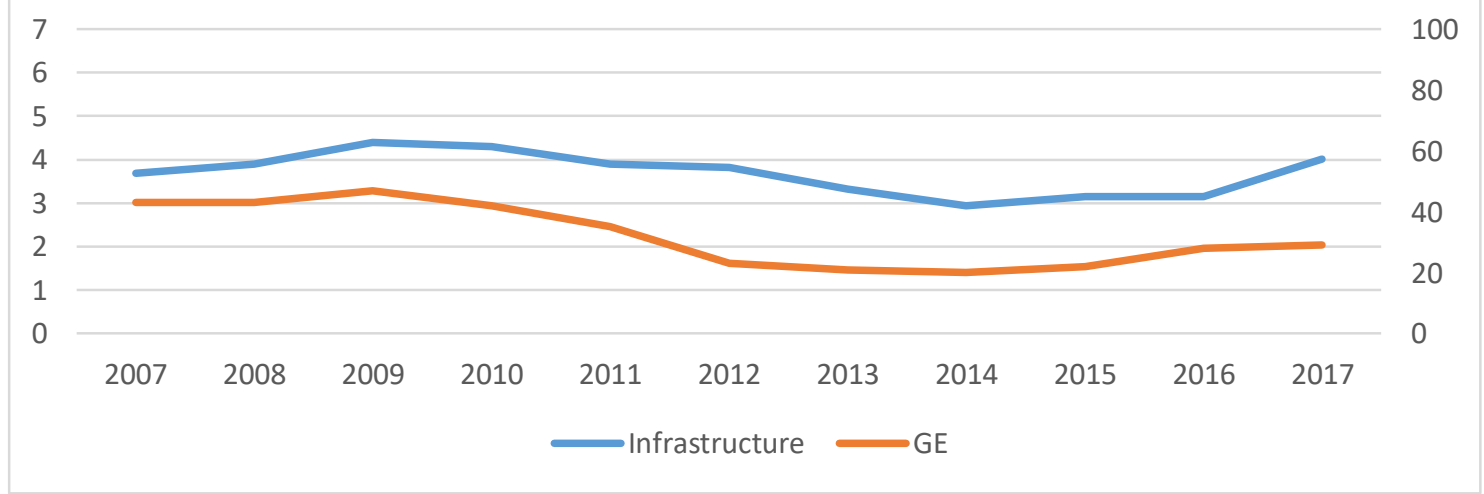

Figure1: Infrastructure \& GE in Egypt. Source WGI and Global Competitiveness Index ${ }^{1}$. 


\section{(c) Center for Promoting Education and Research}

The graph shows that there is a correlation between both indicators. The highest value for infrastructure is 4.1 which was reached in both 2008 and 2016 while the lowest value was 3.2 in 2013. The highest value for government effectiveness was in 2009 with a score of 47 and declined since. The lowest value for GE was 20 in 2014.

Infrastructure quality had recovered the declination and returned to its highest numbers again while government effectiveness still could not recover to the values before 2011.

To calculate the coefficient correlation between two variables I applied Pearson product-moment Correlation (PPMC). The result shows $r=0.766$ which is a strong positive correlation between the two variables. That means when the value of one variable increase that increases the other variable.

Throughout the study, GE and infrastructure had many significant ups and downs. Infrastructure quality dropped by over $20 \%$ of its all-time high in 2009 to an all-time low in 2014. The total investment in infrastructure started to drop significantly since 2009. Table 1 shows the total investment percentage to GDP and the amount invested in Egyptian pound. While in term of numbers the amount of investment ranged between 53 to 57 Billion Egyptian pounds, yet the percentage to GDP dropped from 4.67\% in 2009 to 2.19 in 2014.

\section{Table 1 Total percentage of investment to GDP in Egypt. ${ }^{2}$}

\begin{tabular}{|l|l|l|l|}
\hline Years & GDP & $\begin{array}{l}\text { Total amount of } \\
\text { Investment }\end{array}$ & $\begin{array}{l}\text { Percentage } \\
\text { Investment to GDP }\end{array}$ \\
\hline 2007 & 744.8 billion & 27517.7 & $3.69 \%$ \\
\hline 2008 & 895.5 billion & 41833.1 & $4.67 \%$ \\
\hline 2009 & 1.042 trillion & 46082.9 & $4.42 \%$ \\
\hline 2010 & 1.207 trillion & 46957.6 & $3.89 \%$ \\
\hline 2011 & 1.371 trillion & 46316.6 & $3.38 \%$ \\
\hline 2012 & 1.675 trillion & 52348 & $3.13 \%$ \\
\hline 2013 & 1.86 trillion & 42211.3 & $2.27 \%$ \\
\hline 2014 & 2.13 trillion & 46570.1 & $2.19 \%$ \\
\hline 2015 & 2.444 trillion & 82314.5 & $3.37 \%$ \\
\hline 2016 & 2.709 trillion & 159165.4 & $5.88 \%$ \\
\hline 2017 & 3.47 trillion & 161587.3 & $4.66 \%$ \\
\hline
\end{tabular}

As what will follow, most of the investment in public infrastructure in Egypt is from public investment. Between 2009 and 2014 over 6 government cabinet changed in Egypt. Some of them lasted for several days during the 2011 turmoil. Egypt does not depend on foreign investment in infrastructure and due to political disturbance, that occurred in this period public investment in infrastructure was affected negatively. Accordingly, the quality of infrastructure affected too.

\section{Trends in infrastructure investment}

In this section, I will review the long-term trends of investment in infrastructure in Egypt. The data used are aggregated from the central bank of Egypt and differentiated to public and private investment for four infrastructure sectors; electricity, transportation, Suez Canal and Water. It measures the investment percentage to GDP.

\footnotetext{
${ }^{2}$ Source: data drawn from Central Bank of Egypt and the table is conducted by the author

${ }^{3}$ In Egyptian pound

${ }^{4}$ In Egyptian pound

${ }^{5}$ Total amount of investment in Transportation, electricity, water and Suez Canal
} 


\section{(C) Center for Promoting Education and Research}

WWW.cpernet.org

In a study by World Bank (2010) the time path of total infrastructure investment was examined between 1960 till 2007. The investment consists of two infrastructure sectors: transportation and communication and electricity. The study shows that total investment rose until the late 1980s and declined thereafter till the mid-2000s when it stabilized. Since 2000s total investment had returned to its levels of 1960s which is $5 \%$ of GDP. The public investment has been a dominant force for over four decades. Private investment started to increase since the mid1980s. What is considerable is that the decline in public investment in the last two decades had not been complemented by the private sector. That resulted in an overall declination in total investment as shown in table 1 .

In this study, we will depict the time path in the more recent period between 2007-2017 by the destination of four sectors and by sector of origin. The Global competitiveness index started to release its data on a yearly basis since 2007 so that would be our starting point. Also, World Governance indicators latest data is due 2017 at the time of writing the dissertation that why I chose data between 2007-2017 period. The data will cover four infrastructure sectors: transportation, electricity, water, and the Suez Canal.

Panels (A)-(D) of Figure 2 shows infrastructure investment (public, private and total) as a ratio to GDP between 2007-2017 for the destination of the four sectors. Panel (C) and (D) show that shares of investment of both water and Suez Canal are quite small compared to the other two sectors. Investment in water sector decreased drastically since its highest number in 2009, while Suez Canal has increased significantly in 2015 which can be understood because of the New Suez Canal project which cost 8 billion USD (Knecht, 2015). The public sector plays a major role in the investment of electricity, transportation, Suez Canal and water sectors.

The findings in transportation (A) and electricity (B) show that public investment has fallen in electricity sector until it has almost doubled during 2017 while the transportation sector has fallen in both private and public investment since its highest number in 2008 and could not recover since.

(Percentage of GDP) $)^{6}$

\section{(A) Transportation}

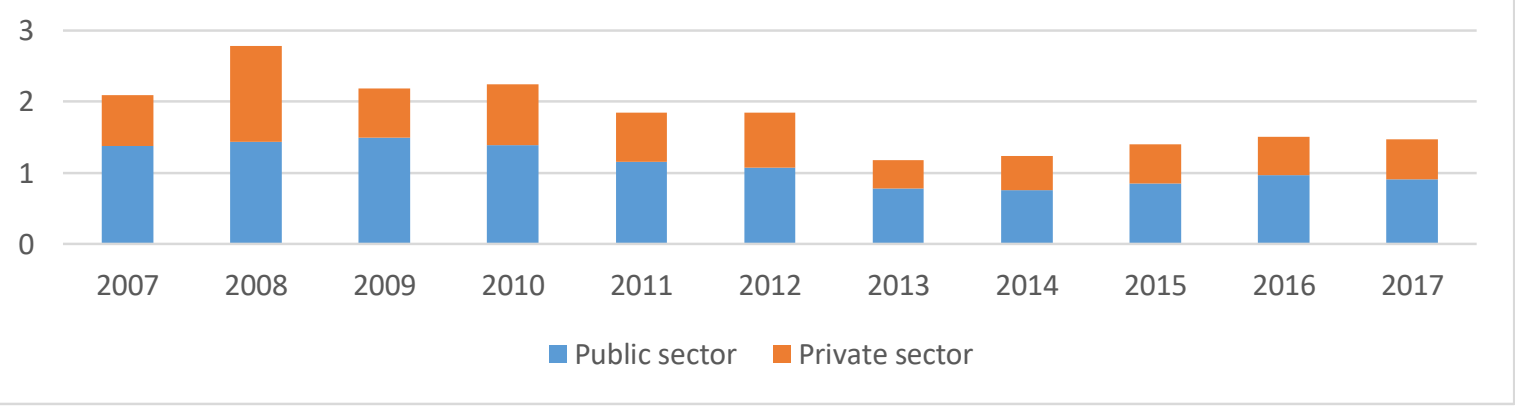

(B) Electricity

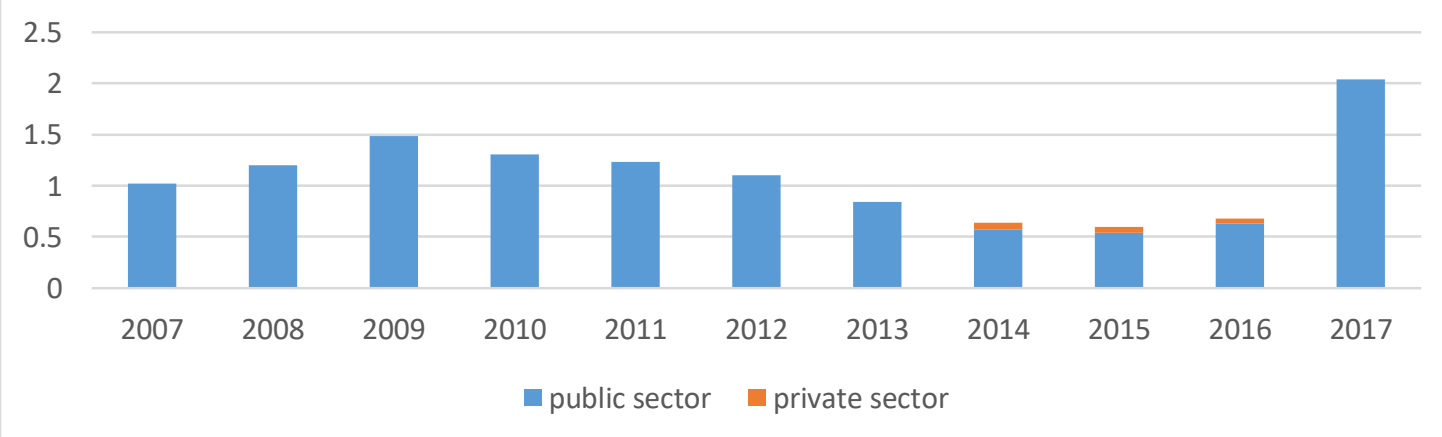

${ }^{6}$ Data from Central Bank of Egypt 

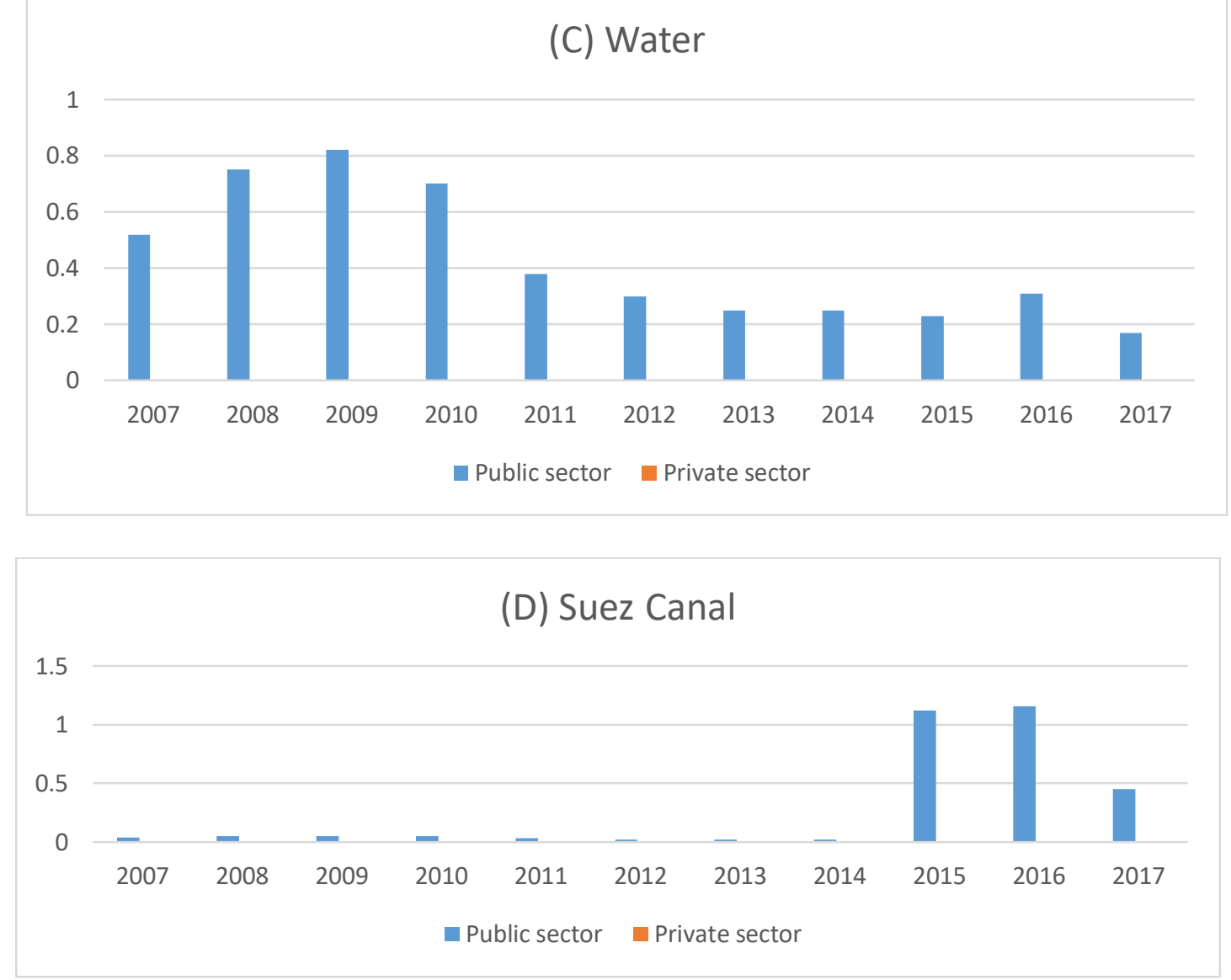

Figure 2: Infrastructure Investment in Egypt (2007-2017).

As shown it appears that only the transportation sector had some little percentage of private investment. The water and electricity sector had been in a low of financial self-sufficiency. Those sectors could not cover their operations and maintenance expenses and the government had to finance both of them (DoingBusiness,2018). The financing gap had multiple reasons like low tariffs for consumers, high per capita consumption and poor collection of tariffs. In Transportation private sectors provide better quality and performance while at the same time is not subsidized by the government. That created a competitive environment for private companies to compete in the market (Ikram, 2017).

\section{Investment expenditure and improvement in infrastructure}

In the world bank study, they compared the level of infrastructure investment in Egypt to that of other developing countries between 2000-05 against GDP percentage. The findings were that total and public investment "fall as the income level of the country increases, while the opposite happens for private investment." (Norman \& Rei, 2010, p. 33).

This may indicate that poorer countries tend to make larger infrastructure through public investment until building a decent level of infrastructure assets and as they became richer they spend less in building new infrastructure and focus on maintaining the existing one. The findings found that while public investment in infrastructure in Egypt is much larger than what would be expected according to the country's income level, its private investment is considerably smaller than the standard set by other developing countries.

The study draws a regression line which represents the median for total investment with GDP. According to the study, Egypt is located on the predicted regression line between 2000 and 2005. While public investment in infrastructure in Egypt is much larger than what would be expected according to the country's income level, its private investment is considerably smaller than the standard set by other developing countries. 


\section{(c) Center for Promoting Education and Research}

WWW.cpernet.org

The study examined the relationship between investment expenditure and improvement in infrastructure. It concluded that there is a positive connection between improvement and investments in infrastructure. However, "any economically important Improvement in the infrastructure indices would take a relatively long time if investment Expenditures are maintained at moderate levels." (Norman \& Rei, 2010, p. 42)

Figure 3 shows the relation between investment in infrastructure as a percentage of GDP and Egypt's rank for infrastructure pillar using the Global Competitiveness Index. It shows the infrastructure rank out of 137 countries with a lower number means better ranking. Egypt best rank was 55 in 2009 where the percentage was $4.56 \%$. Since 2010 the percentage of investment decreased which was accompanied by deteriorating in Egypt's infrastructure rank. Using Pearson product-moment Correlation $(\mathrm{PPMC}), \mathrm{r}=-0.856$ which means strong negative relation. The result confirms that if investment percentage increase the rank will be lowered which means better results and vice versa.

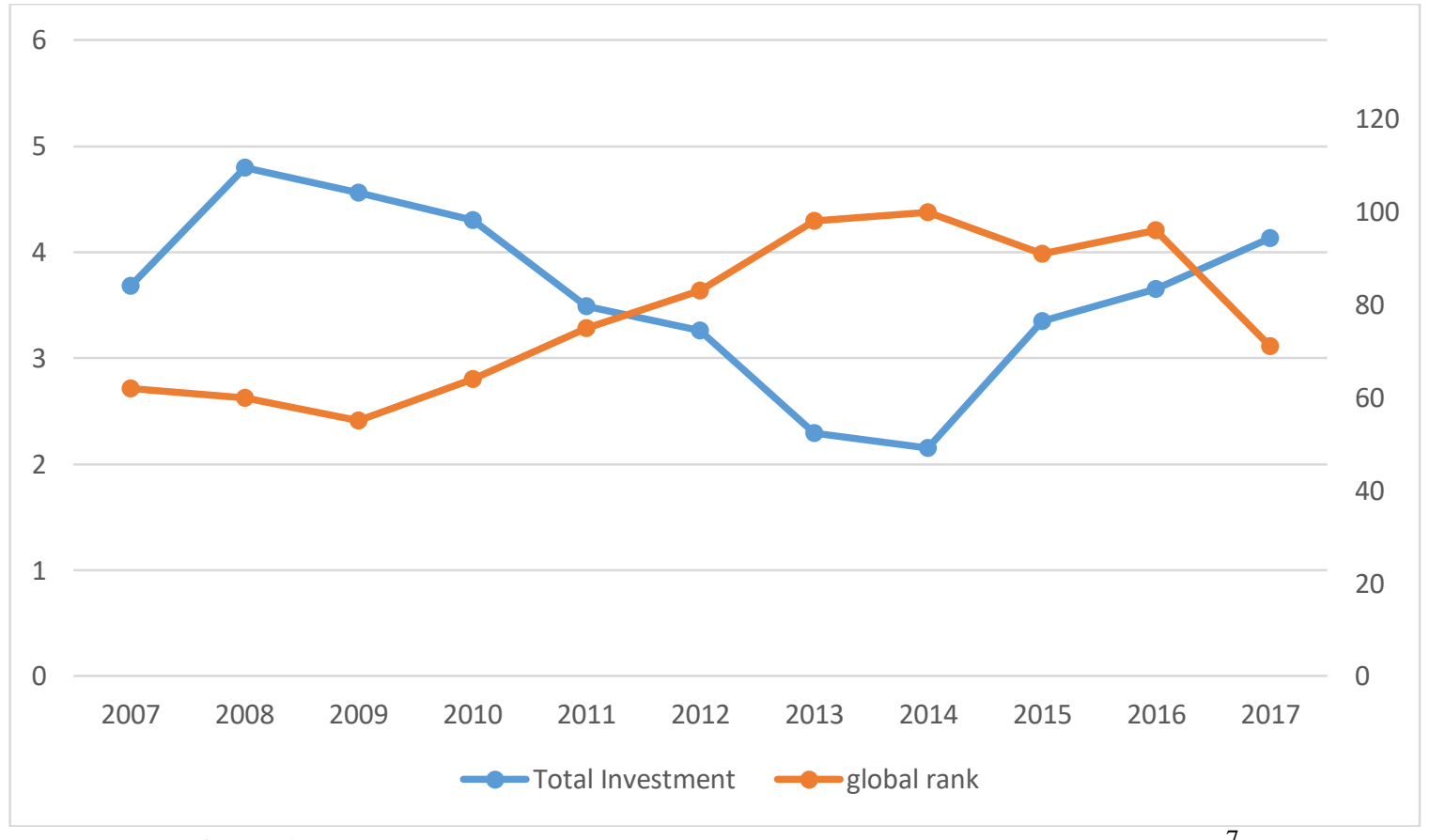

Figure 3: infrastructure pillar rank to total investment (as a percentage of GDP) ${ }^{7}$.

In the final chapter of this study, I will discuss what are the options and opportunities where Egypt can improve its investment in infrastructure which will be translated into better infrastructure service and better government effectiveness.

\section{conclusion}

As has been shown, government effectiveness has a very strong positive correlation with the infrastructure pillar in Egypt. The government effectiveness captures the perception of service quality of infrastructure and the quality of policy formulation and implementation. As per discussed, infrastructure quality service is affected by the percentage of investment of GDP. The higher the percentage of investment the better rank Egypt's get in infrastructure quality. The chapter concluded that Egypt needs to increase infrastructure expenditure to provide a better quality of service.

Egypt depended mainly on public investment to finance its infrastructure. In average infrastructure financing percentage ranged between 2-5\% throughout 2007-2017. According to G20's Global Infrastructure Outlook (2017), Egypt will have a significant financing gap over the next 20 years. While Egypt could provide US\$ 445 billion to finance infrastructure projects, yet it needs US\$675 billion to fulfil its needs which result in US\$230 billion

7 Data from central bank of Egypt and Global Competitiveness Index 
investment gap. The transportation sector accounts for US $\$ 180$ billion of that gap while water infrastructure requires US\$45 billion.

Figure 4 shows the infrastructure project finance volumes in emerging countries. It shows that Egypt has a very small volume comparing to same counterpart countries which have same GDP average like South Africa, Philippines, Thailand, and Peru and with counterpart countries that have similar credit ratings like Ghana, Georgia, and Jamaica.

Egypt has a considerable opportunity to finance its infrastructure investment gap through private investment. A public-private partnership could be adopted as it provides the fastest gains in efficiency (EL-DIN, 2014). For instance, a PPP project can increase revenue by implementing a better user fee by offering incentives for operators to provide better quality in road service. That means financing projects would shift from reliance in taxpayers to user fees model. This model depends on utilizing assets in a greater way and improves asset utilization for users and as a result, the user will be willing to pay for the service.

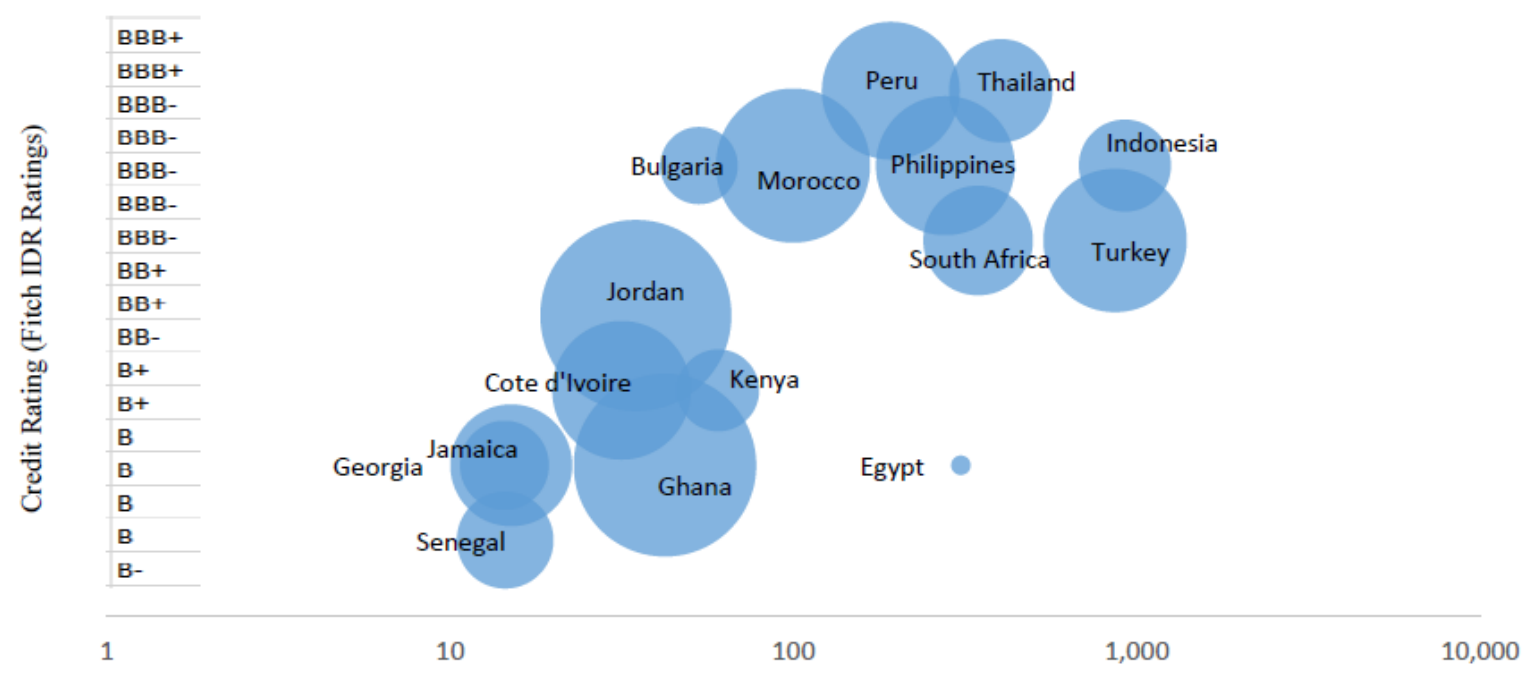

Average GDP (billion, current US\$̦) 2012-2016

Bubble size reflects project finance volumes as a percent of GDP. X axis refers to GDP size, and $Y$ axis reflects international credit rating. Sources: Reuter's, PFI, IJ Global, PPI database, market sources.

Figure 4 : Infrastructure Project Finance Volumes in Emerging Countries Source: World Bank (WorldBank, 2018).

A shift toward user funding instead of taxpayer funding as well as provide better finance to the key economic sector can help Egypt to catch up with its peers. The government must handle first with the business environment to facilitate increased private investment. Facilitating the environment have three dimensions according to the World Bank (2018, p. 3);

- Strengthening institutional and sector frameworks to deliver strategic infrastructure on time, within budget, and in a manner that is cost-efficient, affordable, and above all beneficial to users and citizens. This is particularly important because the weak institutional capacity (lack of organizational, technical, and commercial skills, coordination, and experience) can undermine project development. Consequently, this may result in expensive contracts, failed biddings, or (if relevant) a project being unable to attract private financing.

- Transitioning towards financial independence by adjusting tariffs and tariff-setting approaches to ensure sustainable and adequate revenue streams, as well as to improve operational performance and efficiency. Currently, most of the subject sectors operate under regulated prices set by the government. Sector entities, under varying institutional structures, are currently set at below-cost recovery levels. This means that 
significant fiscal transfers are needed in some cases to support operations and in many cases to support new investments.

- Clarifying project plans and priorities to help potential investors better understand investment pipelines and, where relevant, the competitive environment for proposed projects.

In the strategic level, Egypt has the number of opportunities in transportation, energy and water, and sanitation sectors. In the transportation sector, Egypt can leverage on its geostrategic positions. That can enable Egypt to become a regional hub for logistics and trade. Alongside increase domestic connectivity which can solve urban needs, increase market accessibility to lagging areas and linking local and international markets.

Egypt has to work also on securing and diversification of its energy sources. Depending on renewable energy sources, modernizing oil \& gas sectors and energy efficiency would be a priority (weforum, 2018).

Finally, according to the United Nations, by 2025 Egypt will face an "absolute water crisis". That will have a direct negative effect on agriculture. Therefore, the government needs to improve water and sanitation sectors by focusing on better collection efficiency as well as reducing technical and commercial losses.

\section{References}

Jäger , J. \& Köhler, . B., 2007. Theoretical Approaches to Regional Governance. the University of Applied Sciences bfi Vienna.

Adcock, R. \& Collier, D., 2001. Measurement validity: A shared standard for qualitative and quantitative research. The American Political Science Review, 95(3), p. 529-546..

AUGUSTO, . L.-C.et al., 2006. WEF_GlobalCompetitivenessReport_2006-07, s.1.: the World Economic Forum.

Bang, H. (., 2003. Governance as social and political communication, Manchester, UK.: Manchester University Press..

Behn, R., 2001. Rethinking democratic accountability., Washington, DC: Brookings Institution.

Bevir, M., 2007. Encyclopedia of Governance. California: Rolf Janke.

Cheema, G. S. \& Rondinelli, D. A., 2007. From Government Decentralization to Decentralized Governance. In: G.

S. Cheema \& D. A. Rondinelli, eds. Decentralizing Governance: Emerging Concepts and Practices. Washington, D.C.: brookings institution press, p. 337.

DoingBusiness, 2018. Doing Business 2019, s.l.: The World Bank.

EL-DIN, K. B., 2014. Privatization: A Key to Solving Egypt's Economic Woes. [Online] Available at: https://blogs.worldbank.org/arabvoices/privatization-key-solving-egypt-s-economic-woes [Accessed 75 2019].

GLOBAL INFRASTRUCTURE OUTLOOK, 2017. infrastructure investment needs 50 countries, 7 sectors to 2040, s.1.: Oxford Economics.

Ikram, K., 2017. The Political Economy of Reforms in Egypt. Cairo: The American University in Cairo Press.

IMF, 2017. Arab Republic of Egypt: Request for Extended Arrangement Under the Extended Fund FacilityPress Release; Staff Report; and Statement by the Executive Director for the Arab Republic of Egypt, s.l.: s.n.

Johnson, I., 1997. REDEFINING THE CONCEPT OF GOVERNANCE, s.l.: Canadian International Development Agency.

Katsamunska, P., 2016. The Concept of Governance and Public Governance Theories. Economic Alternatives, Issue issue 2, pp. 133-141. 
Kaufmann, D., Kraay, A. \& Mastruzzi, M., 2010. Response to 'What do the Worldwide Governance Indicators Measure?'. European Journal of Development Research, 22(doi:10.1057/ejdr.2009.49), p. 55-58.

Kaufmann, . D., Kraay, . A. \& Mastruzzi, M., 2007. Governance matters VI: Aggregate and individual governance indicators 1996-2006, Washington DC: World Bank..

Kaufmann, D., Kraay, A. \& Mastruzzi, M., 2010. Response to: "The Worldwide Governance Indicators: Six, One, or None", s.l.: World Bank.

Kaufmann, D., Kraay, A. \& Mastruzzi, M., 2010. The Worldwide Governance Indicators methodology and Analytical issues, s.l.: The World Bank.

Kaufmann, D., Kraay, A. \& Mastruzzi, M., 2019. Worldwide Governance Indicators (WGI). [Online]

Available at: http://info.worldbank.org/governance/wgi/\#reports [Accessed 1303 2019].

Kickert, W., 1997. Public management and administrative reform in Western Europe, Aldershot, UK: Edward Elgar..

Knecht, E., 2015. Egypt's Sisi launches nationalist New Suez Canal celebration. [Online]

Available at: https://www.reuters.com/article/us-egypt-suezcanal/egypts-sisi-launches-nationalist-new-suez-canalcelebration-idUSKCN0QB1LP20150806 [Accessed 2103 2019].

Lahcen, A. \& Rafik, S., 2016 . Micro and Small Enterprises in Egypt, Cairo: Economic Research Forum.

Mitchell, T., 2007. "Deamland" In Evil Paradises: Dreamworlds of Neoliberalism. New York and London: The New Press.

Norman, . V. L. \& Rei, O., 2010. Infrastructure and Economic Growth in Egypt, s.1.: The World Bank. $\mathrm{UN}, 2009$. What is Good Governance?, s.l.: s.n.

weforum, 2018. Arab World Competitiveness Report, s.1.: World Economic Forum.

WorldBank, 2018. Enabling Private Investment and Commercial Financing in Infrastructure, Washington DC: World Bank Group.

.الحميلي, ع., 2018. بنية مقترحة لتسحسين وضع الملكية الفكرية في مصر, القاهرة: المركز المصري لألدر اسات السياسيات العامة.

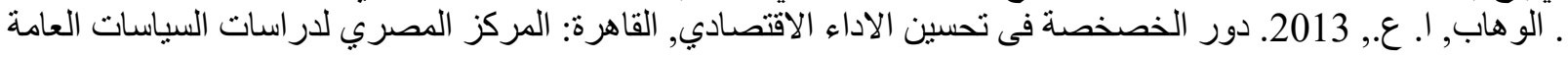

2019. حافظ, أ موجات الخصخصة في مصر 1993 - 2011, اسطنبول: المعهد المصري لللر اسات. 